\title{
ПРОБЛЕМИ УПРАВЛІННЯ
}

УДК 338.3+330.3

Й. М. Петрович, Н. С. Савоніна

Національний університет «Львівська політехніка», кафедра менеджменту організацій

\section{ЗАБЕЗПЕЧЕННЯ НЕПЕРЕРВНОГО МОНІТОРИНГУ ПРОЦЕСІВ МОДЕРНІЗАЦІЇ ОРГАНІЗУВАННЯ ВИРОБНИЧОЇ ДІЯЛЬНОСТІ ПРИЛАДОБУДІВНИХ ПІДПРИЕМСТВ}

\author{
() Петрович Й. М., Савоніна Н. С., 2017
}

Розроблено алгоритм моніторингу результативності процесу модернізації організування виробничої діяльності приладобудівного підприсмства та описано шляхи його реалізації, що забезпечує достовірність і адекватність отримуваної оцінки результативності процесу модернізації на підприємстві та може бути важливим інструментом їі оперативного контролю і планування коригувальних дій. Для моніторингу результативності процесу модернізації організування виробничої діяльності приладобудівного підприсмства запропоновано використовувати «Індекс модернізації організування виробничої діяльності», що формусться на основі виробничої функції 3 використанням розрахованих вагових коефіціснтів та коефіціснтів організування виробничої діяльності за основними виробничими чинниками.

Ключові слова: модернізація, моніторинг, ефективність модернізації

Yo. Petrovych, N. Savonina

Lviv Polytechnic National University, Management of Organizations Department

\section{PROVIDING NON-EXTERNAL MONITORING \\ OF MODERNIZATION ORGANIZATION OF MANUFACTURING OF APPLIED CONSTRUCTION ENTERPRISES}

(C) Petrovych Yo, Savonina N., 2017

To achieve the goals and tasks of modernizing the organization of production activities, it is advisable to monitor its effectiveness. In the process of managing the entire enterprise, or a separate structural subdivision, there are large number of unforeseen procedures for managing situations and uncertainties. Decision-making in emerging situations largely depends on the system of process monitoring, which gives grounds for making conclusions about the correctness of the decision in a particular situation.

Existing evaluation methods today can be described by one algorithm. An algorithm for monitoring the effectiveness of the process of modernizing the organization of the production activity of the instrument making enterprise is described, and the ways of its implementation are described, which ensures the reliability and adequacy of the received assessment of the effectiveness of the modernization process at the enterprise and can be an important tool for its operational control and planning of corrective actions. The model of monitoring of the effectiveness of the process of modernization of the organization of the production activity of the device-making enterprise proposed in this paper is based on the use of the production function of the Cobb-Douglas. To monitor the effectiveness of the process of modernizing the 
organization of the production activity of the instrument making enterprise, it is proposed to use the "Index of modernization of the organization of production activity", which is formed on the basis of the production function, using the calculated weighting coefficients and the coefficients of organizing the production activity by the main production factors.

The use of the process approach allows monitoring and measurement to be made, to determine the state of the enterprise's production activity at the moment, and to predict its future status. At the same time, monitoring should provide justification, and measurements in the monitoring process should ensure the reliability of the results.

Key words: modernization, monitoring, efficiency of modernization

\section{Постановка проблеми}

У процесі модернізації організування виробничої діяльності приладобудівних підприємств може виникати певна кількість непередбачених ситуацій і невизначеностей. Тому прийняття адекватних рішень у таких ситуаціях багато в чому залежатиме від особливостей моніторингу процесу модернізації, результати якого слугуватимуть підставою для прийняття відповідних висновків та проведення необхідних заходів організаційно-технічного спрямування. Отже, для досягнення цілей та завдань модернізації організування виробничої діяльності, доцільно здійснювати моніторинг іiі результативності.

\section{Аналіз останніх досліджень і публікацій}

Теоретичними і практичними аспектами моніторингу і діагностики ефективності діяльності підприємств присвячено багато наукових досліджень закордонних і вітчизняних економістів, серед яких автори [1-15]: Забродський В. А., Зінченко В. А., Кизим М. О., Копчак Ю. С., Мельник О. Г., Новаківський І. І., Твердохліб М. Г., Фомин В. Н., Чуліпа І. Д., Шарапов О. Д., Шершньова 3. Є. та ін. Наукові роботи торкаються питань оцінки і діагностики фінансової стійкості підприємства, необхідності моніторингу в системі управління підприємством, прийняття ефективних рішень, які грунтуються на результатах моніторингу. Проте актуальними залишаються питання формування комплексного показника моніторингу організування виробничої діяльності та розроблення алгоритму моніторингу результативності модернізації організування виробничої діяльності приладобудівного підприємства.

\section{Постановка цілей}

Дослідження процедури моніторингу зумовило постановку таких цілей дослідження:

- розробити алгоритм моніторингу результативності процесу модернізації організування виробничої діяльності приладобудівного підприємства та визначити шляхи його реалізації;

- запропонувати показник оцінювання моніторингу результативності процесу модернізації.

\section{Виклад основного матеріалу}

Використання інформації, інформаційних систем та комунікацій мають вирішальне значення для успіху організаційно-виробничої діяльності в сучасному складному виробництві. Інформація, а також системи і комунікації, що ії надають, пронизують усі рівні сучасних організацій. Стандарт ДСТУ ISO 9001-2015 вимагає щоб організація застосовувала відповідні методи моніторингу там, де це доцільно. Для виконання цієї вимоги кожному підприємству необхідно визначити свої вимоги до моніторингу і правила його виконання, щоб продемонструвати здатність процесів досягати запланованих результатів, або розробляти і запроваджувати коригувальні і (або) випереджувальні дії для забезпечення виготовлення якісної продукції. На підприємстві повинна існувати чітка процедура ведення постійної звітності про проведення моніторингу, яка необхідна для того, щоб оцінити рівень розвитку його виробничої діяльності та пї вплив на економічні показники підприємства.

Застосування досягнення мети моніторингу процесів модернізації організування виробничої діяльності приладобудівних підприємств складається із сукупності методів теоретичного і практичного спрямування. 3 позиції теорії опис і характеристика моніторингу знаходить висвітлення у його методології, з позиції практики - в ефективність і дієвість усього інструментарію моніторингу в умовах реального виробництва. Наявність складних сучасних ієрархічних виробничих систем 
зумовлює таку варіативність, за якою системи моніторингу можуть відображати лише найсуттєвіші характеристики того чи іншого об'єкта. При цьому важливим $є$ вибір механізмів із заданим рівнем критеріїв оцінювання функціонування підприємства залежно від реальних і прогнозованих умов його функціонування. Тому система моніторингу процесів модернізації, у своєму найефективнішому форматі, повинна бути пов'язана 3 стратегічним управлінням підприємством, яке $\epsilon$ вихідним пунктом розробки цільових планів, стратегічних та оперативних планів, переліку ключових планових показників виробничої діяльності підприємства [1].

У процесі управління усім підприємством, чи окремим структурним підрозділом, виникає велика кількість непередбачених процедурою управління ситуацій та невизначеностей. Прийняття рішення у ситуаціях, що виникають, багато в чому залежить від системи моніторингу процесів, яка дає підстави робити висновки щодо правильності прийнятого рішення в конкретній ситуації. Моніторинг є безперервним процесом збору, обробки, оцінки та підготовки рішень, спрямованих на досягнення цілей та завдань, які поставлені перед підприємством. Водночас процеси моніторингу залежать від потреб та умов конкретного підприємства. В цьому полягають загальні принципи їхнього формування:

1. всесторонність - моніторинг повинен бути всестороннім, грунтуватися на простих i зведених вимірюваннях, фокусуючись на винятках;

2. відповідність - моніторинг повинен відповідати місії, баченню, цілям і стратегії підприємства;

3. прийнятність - ефективний метод моніторингу повинен бути прийнятним для його об'єктів, необхідно поважати їхній особистий простір та не втручатись в повсякденні обов' язки;

4. своєчасність - дані моніторингу повинні бути доступними, що дозволить виявляти відхилення, про які потрібно негайно повідомити відповідну керівну ланку для прийняття правильних і оперативних рішень;

5. доказовість - інформація, отримана в ході моніторингу, повинна піддаватись перевірці іншими засобами, тобто бути точною i, по можливості, базуватись на реальних фактах;

6. динамічність - будь-яка форма моніторингу повинна допускати оперативні коректувальні заходи;

7. гнучкість (адаптованість) - система моніторингу повинна легко адаптуватися, забезпечуючи точну, значиму та своєчасну інформацію в мінливих обставинах.

Поряд із застосуванням основних принципів моніторингу, важливе значення має визначення методичних підходів щодо використання відповідних механізмів оцінювання під час проведення моніторингу. Особливо серйозну роль в цьому контексті відіграють комплексні підходи щодо оцінювання шляхом використання показників, тобто оцінки показників, що належать до сукупності, що характеризує певні властивості. Ймовірно, важливість комплексних оцінок і та увага, яку приділяють їм дослідники, призвели до розповсюдження думки, що моніторинг оперує тільки комплексними безрозмірними оцінками, отриманими в результаті обчислення тим чи іншим способом. Це, безумовно, звужує границі моніторингу, оскільки виключає із сфери моніторингу диференційні методи оцінки (тобто оцінки окремих, одиничних показників, властивостей) [3]. Диференційні оцінки є не тільки інструментом моніторингу, але без них неможливо отримати комплексну оцінку [3]. Відповідно, задача моніторингу — застосування усіх методів оцінки (як комплексних, так і диференційних).

В наш час комплексні кількісні оцінки впроваджуються в різні сфери людської діяльності. Існуючі на сьогодні методики оцінки можуть бути описані одним алгоритмом. Таким чином, прийнято вважати, що [3]:

1. методи комплексної кількісної оцінки охоплюють нові сфери, часто суттєво віддалені від початкової сфери їх застосування - тільки до результатів праці;

2. алгоритм цих методів і принципи, на яких вони базуються, практично не відрізняються від тих, що прийняті в теоретичній кваліметрії;

3. сфери застосування багатьох із цих методів, наприклад оцінка якості менеджменту, надзвичайно важливі. 
До найрозповсюдженіших методів моніторингу, які охоплюють широку сукупність процесів, варто зарахувати проведення внутрішніх і зовнішніх аудитів (перевірок) та аналіз запланованих і виконаних заходів.

Основною передумовою здійснення моніторингу результативності процесу модернізації організування виробничої діяльності приладобудівного підприємства є початок реалізації проекту модернізації.

В умовах модернізації організування виробничої діяльності важливу роль відіграє своєчасна $\mathrm{i}$ вірогідна інформація про іiі результативність, яка використовується для підтримки доцільних і ефективних управлінських рішень.

Встановлення цілей моніторингу необхідно для того, щоб забезпечити оцінку впливу модернізації організування виробничої діяльності на функціонування приладобудівного підприємства.

Основною ціллю моніторингу процесу модернізації організування виробничої діяльності приладобудівного підприємства $€$ встановлення певних тенденцій, виявлення їх причин та передумов. Крім спостережень і отримання інформації, моніторинг передбачає і заходи активних дій, таких як оцінювання, прогнозування, розроблення рекомендацій.

Формування поточного плану здійснення моніторингу необхідне для перетворення цілей моніторингу в конкретні плани, визначення пріоритетів, засобів та методів їх досягнення. Поточний план повинен бути змістовно пов'язаним з основними цілями моніторингу.

Під час планування моніторингу повинні брати участь усі працівники, яких цей процес безпосередньо стосується. При цьому кожний із учасників планування одержує глибше розуміння цілей моніторингу та отримує повну і об’єктивну інформацію, про різні шляхи його реалізації. Особиста участь у плануванні працівників приладобудівного підприємства, зокрема і рядових, призводить до того, що плани підприємства стають також і їхніми особистими планами. Застосування принципу участі у плануванні моніторингу сприяє тому, що працівники, займаючись плануванням, розвивають себе як особистість і у кожного з них з'являються нові мотиви до підвищення ефективності праці, а приладобудівне підприємство отримує додаткові ресурси для ефективного вирішення своїх майбутніх завдань.

Також у безперервному вдосконаленні організування виробничої діяльності приладобудівного підприємства, необхідно враховувати принцип безперервності при плануванні моніторингу. Цей принцип передбачає здійснення процесу планування на підприємстві так, щоб розроблені плани безперервно змінювали один одного.

Процес планування повинен бути безперервним, на підставі таких передумов:

1) невизначеності зовнішнього середовища і наявності непередбачених змін, які роблять необхідним постійне коригування планів підприємства відносно змін зовнішніх чинників і відповідне їх коригування;

2) змінюються не лише передумови, але й уявлення працівників підприємства про свої внутрішні цінності та можливості.

Ще одним важливим етапом підготовки до моніторингу є деталізація поточного плану за центрами виконання. Відомо, що центри виконання (відповідальності) - це підрозділи, служби, групи на підприємстві, які є відповідальними за виконання певних робіт, реалізацію визначених заходів та досягнення певного рівня результативності.

Після цього відбувається перехід безпосередньо до моніторингу результативності процесу модернізації організування виробничої діяльності.

Особливу увагу необхідно звернути на виділення та розподіл ресурсів, що необхідні для здійснення моніторингу з метою забезпечення раціонального розподілу ресурсів між окремими напрямками та підрозділами i їх ефективного використання для якнайкращого досягнення поставлених цілей моніторингу результативності процесу модернізації організаційно-виробничої діяльності приладобудівного підприємства.

При плануванні моніторингу результативності модернізації організування виробничої діяльності приладобудівного підприємства, необхідно врахувати забезпечення фіксації даних для 
розрахунку фактично досягнутих показників у певні проміжки часу. Збір фактичних даних для розрахунку показників може здійснюватись за допомогою інструментальних методів, тобто за допомогою вимірювального обладнання; анкетування та опитувань; експертних оцінок та аудитів.

Отже, моніторинг результативності процесу модернізації організування виробничої діяльності підприємства $є$ важливим інструментом зменшення втрат виробництва. Тут важливо зазначити, що приладобудівне підприємство є складною організаційно-виробничою системою, то виникають значні труднощі при оцінюванні відповідності його процесів встановленим вимогам.

Важливим підгрунтям оперативного контролю стану підприємства та процесу планування коригувальних дій 3 його вдосконалення повинна стати методика моніторингу процесів за показниками результативності.

Необхідно мати на увазі, що згідно з ДСТУ ISO 9001:2015 організація повинна визначити, які види моніторингу і вимірювань здійснюватимуться, а також яке відповідне контрольне i вимірювальне устаткування, необхідне для надання доказів відповідності продукції встановленим вимогам [7]. У зв'язку з тим, що моніторинг охоплює комплекс необхідних процедур і дій 3 управлінських і вимірювальних процесів, то є доцільним введення спеціального показника, за допомогою якого можна оцінити результативність виконання вимог стандарту ДСТУ ISO 9001:2015. В цьому контексті запропоновано підхід до моніторингу результативності процесів модернізації організування виробничої діяльності приладобудівного підприємства за допомогою узагальненого показника.

Для вирішення цього завдання, тобто моніторингу результативності процесу модернізації організування виробничої діяльності приладобудівного підприємства доцільно використовувати виробничу функцію - економетричну модель, яка кількісно описує зв'язок основних результативних показників виробничої діяльності підприємства 3 чинниками, що визначають ці показники. До основних показників можна зарахувати дохід, прибуток, рентабельність, продуктивність праці, собівартість і т. ін.

Формування моделі моніторингу результативності процесу модернізації організування виробничої діяльності приладобудівного підприємства основана на використанні виробничої функції Кобба-Дугласа у такому вигляді:

$$
Q=L^{\beta 1 *} K^{\beta 2 *} M^{\beta 3},
$$

де Q - обсяг виробництва продукції (грн); L - витрати на оплату праці (вартість людського капіталу), грн; $\mathrm{K}$ - вартість обладнання (основних засобів), грн; М - вартість матеріалів та сировини (грн).

При цьому сума значень вагових коефіцієнтів $\beta_{1}+\beta_{2}+\beta_{3} \sim 1$.

Розрахунок значень вагових коефіцієнтів $\beta 1, \beta 2, \beta 3$ автор здійснив на основі щоквартальних статистичних даних таких приладобудівних підприємств: НВПП «Спаринг-Віст центр», ТзОВ «Завод Електронпобупприлад» та ТОВ «Мікрокод» ЛТД протягом 2014 - 2016 років, шляхом вирішення наведеного багатофакторного рівняння регресії:

$$
\ln Q=\beta \ln L+\beta 2 \ln K+\beta 3 \ln M,
$$

де Q - обсяг виробництва продукції (грн); L - витрати на оплату праці (вартість людського капіталу), грн; К - вартість обладнання (основних засобів), грн; М - вартість матеріалів та сировини (грн); $\beta 1, \beta 2, \beta 3$ - вагові коефіцієнти. На основі побудованої таблиці (додаток Б), за допомогою функції регресії, знайдено такі значення вагових коефіцієнтів: $\beta_{1}=0,08 ; \beta_{2}=0,14 ; \beta_{3}=0,78$, які було використано для розрахунку індексу модернізації організування виробничої діяльності приладобудівного підприємства $\left(I_{Q}\right)$.

Автори здійснили практичну апробацію розрахунку «Індексу оцінювання модернізації організування виробничої діяльності» НВПП «Спаринг-Віст Центр» у 2016 році. 
Розрахунок індексу модернізації організування виробничої діяльності було здійснено так:

- На основі статистичних даних розраховано сумарні річні значення $\mathrm{L}_{\text {баз }} ; \mathrm{K}_{\text {баз }} ; \mathrm{M}_{\text {баз }}$ за 2015 рік (базові значення) та річні значення L; K; M за 2016 рік (табл. 1).

- Після цього розраховано річні значення коефіцієнтів $E_{1} ; E_{2} ; E_{3}$ за 2016 рік (табл. 1).

- Здійснено розрахунок індексу оцінювання модернізації організування виробничої діяльності ( $\left.I_{Q}\right)$ (табл. 1) за співвідношенням:

$$
I_{Q}=\frac{\left(L \cdot E_{1}\right)^{\beta_{1}} \cdot\left(K \cdot E_{2}\right)^{\beta_{2}} \cdot\left(M \cdot E_{3}\right)^{\beta_{3}}}{L_{\text {бas }}^{\beta_{1}} \cdot K_{\text {бas }}^{\beta_{2}} \cdot M_{\text {бas }}^{\beta_{3}}},
$$

де $E_{1} ; E_{2} ; E_{3}$ - коефіцієнти узагальнюючих чинників організування виробничої діяльності; $\mathrm{L}_{\text {баз, }}$ $\mathrm{K}_{\text {баз }}, \mathrm{M}_{\text {баз }}$ відповідно вартість людського капіталу, основних засобів, матеріалів та сировини за 2015 рік (до проведення модернізації), грн; L, K, M - відповідно вартість людського капіталу, основних засобів, матеріалів та сировини за 2016 рік (після проведення модернізації на підприємстві), грн.

\section{Розрахунок «Індексу оцінювання модернізації організування виробничої діяльності» НВПП «Спаринг-Віст Центр»}

\begin{tabular}{|c|c|c|c|c|c|}
\hline Показник & $\begin{array}{l}\text { Значення } \\
\text { показника } \\
\text { за } 2015 \text { рік }\end{array}$ & Показник & $\begin{array}{l}\text { Значення } \\
\text { показника } \\
\text { за } 2016 \text { рік }\end{array}$ & $\begin{array}{c}\text { Величина показника } \\
\text { оцінювання }\end{array}$ & $\begin{array}{l}\text { Значення } \\
\text { показника за } \\
2016 \text { рік }\end{array}$ \\
\hline $\begin{array}{l}\text { Вартість } \\
\text { людського } \\
\text { капіталу }\left(\mathrm{L}_{\text {баз }}\right) \text {, } \\
\text { тис. грн }\end{array}$ & 3293 & $\begin{array}{l}\text { Вартість } \\
\text { людського } \\
\text { капіталу (L), } \\
\text { грн }\end{array}$ & 3402 & $\begin{array}{l}\text { Коефіцієнт } \\
\text { використання } \\
\text { людського капіталу } \\
\left(\mathrm{E}_{1}\right)\end{array}$ & 0,59 \\
\hline $\begin{array}{l}\text { Вартість } \\
\text { основних } \\
\text { засобів }\left(\mathrm{K}_{\text {баз }}\right) \text {, } \\
\text { тис. грн }\end{array}$ & 20144 & $\begin{array}{l}\text { Вартість } \\
\text { основних } \\
\text { засобів (K), грн }\end{array}$ & 21155 & $\begin{array}{l}\text { Коефіцієнт } \\
\text { використання техніко- } \\
\text { технологічної бази }\left(\mathrm{E}_{2}\right)\end{array}$ & 0,60 \\
\hline $\begin{array}{l}\text { Вартість } \\
\text { матеріалів та } \\
\text { сировини }\left(\mathrm{M}_{б а з}\right) \text {, } \\
\text { тис. грн }\end{array}$ & 12106 & $\begin{array}{l}\text { Вартість } \\
\text { матеріалів та } \\
\text { сировини } \\
\text { (М),грн }\end{array}$ & 15022 & $\begin{array}{l}\text { Коефіцієнт } \\
\text { використання } \\
\text { матеріальних ресурсів } \\
\left(\mathrm{E}_{3}\right)\end{array}$ & 0,64 \\
\hline \multicolumn{5}{|c|}{$\begin{array}{l}\text { Індекс оцінювання модернізації організування виробничої діяльності НВПП } \\
\text { «Спаринг-Віст Центр» }\left(I_{Q}\right):\end{array}$} & 0,75 \\
\hline
\end{tabular}

Розраховано авторами за результатами проведеного дослідження.

Визначивши величину індексу оцінювання модернізації, можна зробити відповідний висновок про ефективність проведених заходів, спрямованих на проведення модернізації організування виробничої діяльності. Будь-яка система моніторингу побудована на основі конкретних вимог і за оцінкою відповідності цим вимогам може перебувати у двох станах відповідає або не відповідає. Кожен елемент системи, який оцінюється в процесі перевірки його відповідності вимогам, може мати два стани: «відповідає», «не відповідає». За такої постановки процедура моніторингу процесів еквівалентна задачі перевірки статистичних гіпотез про відповідність елементів організаційної системи встановленим вимогам. Критерій перевірки полягатиме в тому, що гіпотеза про відповідність процесу модернізації організування виробничої діяльності приладобудівного підприємства приймається, якщо за результатами оцінювання значення індексу модернізації ( $I_{Q}$ ) більше, або рівне 0,25 . Якщо виявиться, що значення $I_{Q}$ менше ніж 0,25 ; то приймається гіпотеза про невідповідність процесу модернізації організаційновиробничої діяльності приладобудівного підприємства встановленим вимогам. Після розрахунку 
індексу модернізації організування виробничої діяльності приладобудівного підприємства, необхідно здійснити перевірку його відповідності показників встановленим критеріям.

Підтвердження відповідності застосовується для того, щоб засвідчити і довести факт відповідності результатів модернізації встановленим вимогам.

Згідно з стандартом ISO/IEC 17000:2004, оцінка відповідності є доказом того, що задані вимоги до процесу, системи, особи або органу, виконані. У нашому випадку, оцінка відповідності показників є цілісним процесом, використовуваним для доказу того, що результативність процесу модернізації відповідає встановленим вимогам.

Отже, якщо в результаті перевірки «Індексу модернізації організування виробничої діяльності» приладобудівного підприємства виконується умова $I_{Q} \geq 0,25$, то процес модернізації організування виробничої діяльності підприємства визнається відповідним встановленим вимогам.

В даному випадку значення «Індексу модернізації організування виробничої діяльності» НВПП «Спаринг-Віст Центр» становить 0,75, що дає нам підстави зробити висновок про відповідність цього процесу модернізації встановленим вимогам.

Здійснивши оцінку відповідності показників результативності процесу модернізації організування виробничої діяльності встановленим критеріям, необхідно проаналізувати чи мети моніторингу досягнуто. Після проведення моніторингу, або певного його етапу, здійснюється оцінка відповідності результатів тим цілям, які передбачалися при плануванні моніторингу, аналізуються позитивні й негативні сторони та робляться відповідні висновки. Коли процес моніторингу, чи певний його етап вже завершений, можна його удосконалити, тобто оптимізувати, проаналізувавши отримані результати.

Підтвердження відповідності «Індексу модернізації організування виробничої діяльності» встановленим критеріям є одним із завершальних етапів оцінки результативності процесу модернізації організування виробничої діяльності приладобудівного підприємства.

Завершальним етапом моніторингу результативності процесу модернізації організування виробничої діяльності приладобудівного підприємства $є$ інтерпретація результатів оцінювання. Отже, на завершальному етапі, необхідно надати певний сенс отриманим у процесі моніторингу результатам. Цього можна домогтися шляхом формування відповідного алгоритму моніторингу результативності процесу модернізації організування виробничої діяльності приладобудівного підприємства, який представлений на рисунку.

Впровадження алгоритму моніторингу результативності процесу модернізації організування виробничої діяльності приладобудівного підприємства, дає змогу здійснювати контроль і динаміку впливу усіх виробничих чинників, водночас, враховуючи також пріоритетність окремих чинників на певних підприємствах, шляхом присвоєння відповідним чинникам вагових коефіцієнтів.

Отже, будь-який, достатньо складний процес, може містити дрібніші складові, стан яких повинен відображатись у результаті здійснення моніторингу цього процесу. Планувати можна i саму виробничу діяльність та процес модернізації організування виробничої діяльності, і показники результативності процесу їі модернізації.

Використання процесного підходу дає змогу забезпечити моніторинг і вимірювання, для визначення стану виробничої діяльності підприємства на даний момент та спрогнозувати іi розвиток в майбутньому. При цьому, моніторинг повинен забезпечувати обгрунтованість, а вимірювання, які здійснюються в процесі його проведення, повинні гарантувати достовірність отриманих результатів.

Розглядаючи особливості моніторингу процесів модернізації організування виробничої діяльності приладобудівного підприємства, варто зазначити, що необхідним є дотримання принципу системності їх функціонування 3 визначеною послідовністю етапів, тобто повинні здійснюватися до побудови процесів неперервного моніторингу на підприємстві. 


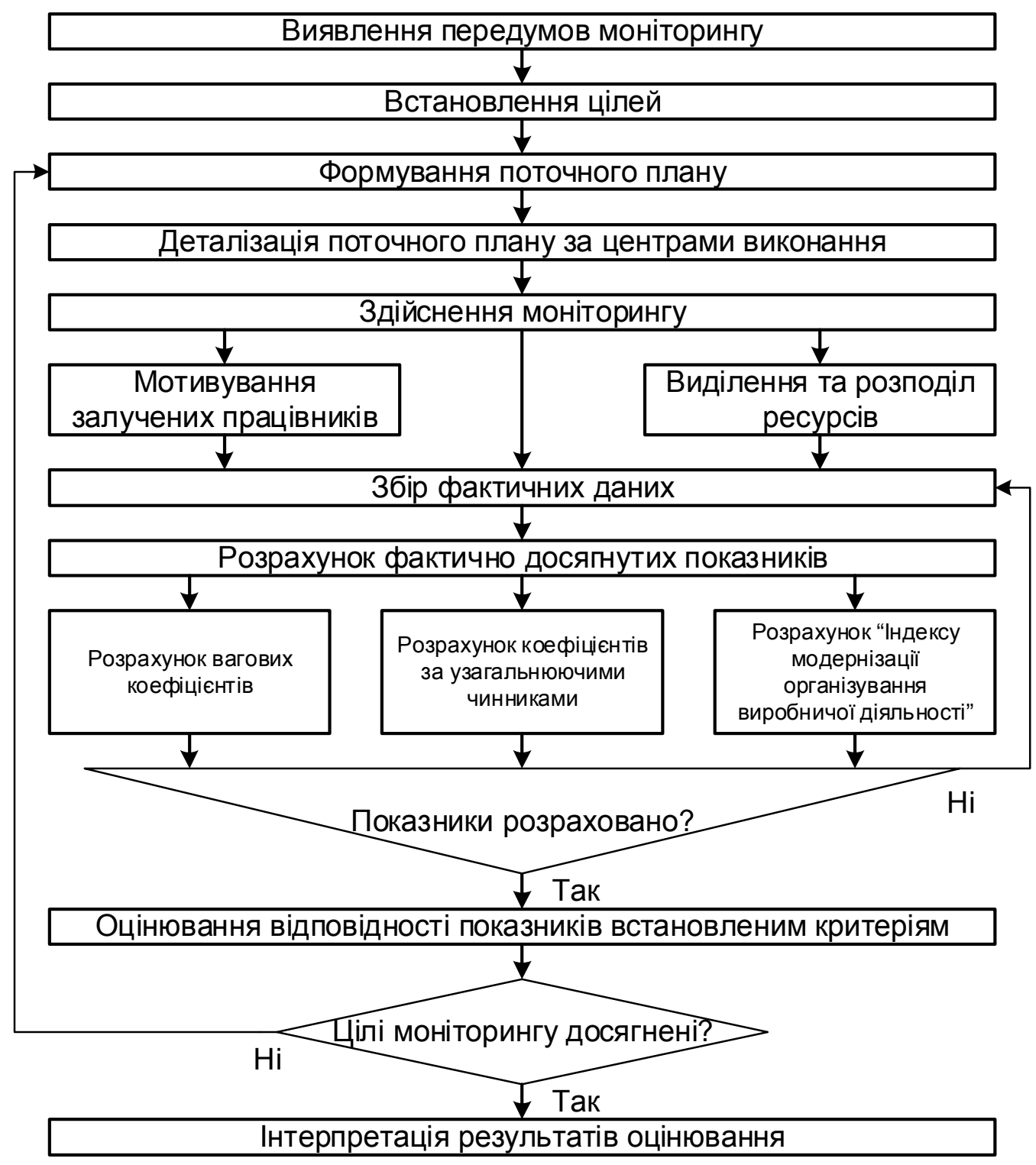

Рис. 1 Алгоритм моніторингу результативності модернізаиії організування виробничої діяльності приладобудівного підприємства

Джерело: розробка авторів

\section{Висновки}

Таким чином, розроблено алгоритм моніторингу результативності процесу модернізації організування виробничої діяльності приладобудівного підприємства за допомогою «Індексу модернізації організування виробничої діяльності», який враховує динаміку зміни результативності основних виробничих чинників у процесі модернізації. Моніторинг результативності процесу модернізації організування виробничої діяльності приладобудівного підприємства спрямований на виявлення відхилень та визначення причин відхилень цього процесу, з метою їх усунення шляхом здійснення відповідних заходів, спрямованих на покращення результатів модернізації.

\section{Перспективи подальших досліджень}

Комплексна оцінка результативності може знайти широке застосування при плануванні процесів модернізації організування виробничої діяльності вітчизняних приладобудівних підприємств. Подальші дослідження можуть спрямовуватися на використання сучасних інфор- 
маційних технологій та комплексних систем моніторингу для підвищення періодичності та рівня достовірності отриманої інформації, використання інтернету речей у промисловості, тощо.

1. Чуліпа І. Д. Передумови розвитку і шляхи вдосконалення моніторингу показників інновачійної діяльності підприємства. Волинський національний університет імені Лесі Украӥнки, 2010. 2. Фомин В.Н. Квалиметрия. Управление качеством. Сертификация. 2-ге вид., перер. і доп. 2007. 583 с. 3. Кузьмін О. С. Теоретичні та прикладні засади менеджменту: навч. посібник / О. Є. Кузьмін, О. Г. Мельник. - Львів: Вид-во «Інтелект-Захід», 2003. - 352 с. 4. Шериньова 3. Є. Антикризова програма підприємства: методичні основи розробки та організація виконання / 3. С. Шершньова // Вісник Хмельницького начіонального університету «Економічні науки». - 2010, № 2, Т. 1, с. 140-144. 5. ДСТУ ISO 9001:2015. 8. Петрович Й. М., Лущзак Н. С. Сутнісна характеристика поняття модернізаиіі підрисмства в системі економічних категорій / Й. М. Петрович // Вісник Нач. ун-ту «Львівська політехніка» «Менеджмент та підприємництво в Україні: етапи становлення і проблеми розвитку». - 2012. - № 748. - C. 199-206. 6. Novakivskii I. Modernization of the manufacturing system of national enterprises by implementing modern information technologies / I. Novakivskii, N. Lushchak // Econtechmod. Lublin - Lviv-Kracow, 2016. - Vol.1. No. 5. P. 73-78. 7. Оиінка і діагностика фінансової стійкості підприємства. / Кизим М. О., Забродський В. А., Зінченко В. А., Копчак Ю. С. - Харків: ВД «IН-ЖЕК», 2003. - 144 c.

1. Chulipa I. D. Prerequisites for development and ways to improve the monitoring of indicators of innovation activity of the enterprise. Volyn National University named after Lesia Ukrainka, 2010. 2. Fomin V. N. Kvalimetry Quality management. Certification 2nd form, per. And add-2007. 583 s. 3. Kuzmin O. Ye. Theoretical and applied principles of management: Teach. manual / O. E. Kuzmin, O. G. Melnyk. - Lviv: View «Intellect-West», 2003. - 352 c. 4. Shershnyova Z. Y. Anticrisis program of the enterprise: methodical bases of development and organization of implementation / Z. E. Shershnyov // Bulletin of the Khmelnytsky National University «Economic Sciences». - 2010. - No. 2, T. 1, p. 140-144. 5. DSTU ISO 9001: 2015. 8. Petrovich YM, Lushchak N. S. Essential characteristic of the concept of modernization of the enterprise in the system of economic categories / J. M. Petrovich // Bulletin of the National Academy of Sciences of Ukraine. Lviv Polytechnic University «Management and Entrepreneurship in Ukraine: Stages of Development and Development Problems». - 2012. - No. 748. P. 199-206. 6. Novakivsky I. Modernization of the manufacturing system of national enterprises by implementing modern information technologies / I. Novakivsky, N. Lushchak // Econtechmod. Lublin Lviv-Kracow, 2016. - Vol.1. No. 5. - P. 73-78. 7. Evaluation and diagnostics of financial stability of the enterprise. / Kizim M. O., Zabrodsky V. A., Zinchenko V. A., Kopchak Yu. S. - Kharkiv: VD «IN-ZHEK», 2003. - 144. 